\title{
A BRIEF OVERVIEW ON VALORIZATION OF INDUSTRIAL TOMATO BY-PRODUCTS USING THE BIOREFINERY CASCADE APPROACH
}

\author{
Marcello Casa ${ }^{1, \star}$, Michele Miccio ${ }^{1}$, Giovanni De Feo ${ }^{1}$, Andrea Paulillo ${ }^{2,3}$, Roberto Chirone ${ }^{2,4}$, \\ Dalia Paulillo ${ }^{2}$, Paola Lettieri ${ }^{3}$ and Riccardo Chirone ${ }^{5}$ \\ ${ }^{1}$ Department of Industrial Engineering, University of Salerno, Italy \\ ${ }^{2}$ eLoop Srl, Italy \\ ${ }^{3}$ Department of Chemical Engineering, University College London, United Kingdom \\ ${ }^{4}$ Department of Chemical, Materials and Production Engineering (DICMaPI), University of Naples Federico II, Italy \\ ${ }^{5}$ Istituto di Scienze e Tecnologie per l'energia e mobilità sostenibili, Consiglio Nazionale delle Ricerche (STEMS-CNR), Italy
}

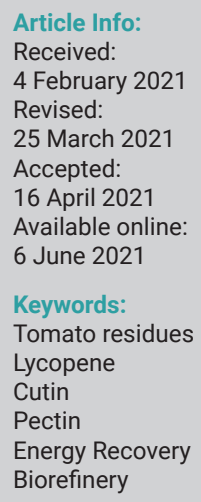

\begin{abstract}
The industrial processing of tomato leads to substantial amounts of residues, typically known as tomato pomace or by-products, which can represent as much as $10 \%$ by weight of fresh tomatoes. At present, these residues are either used as feedstock for animals or, in the worst case, disposed of in landfills. This represents a significant waste because tomato pomace contains high-value compounds like lycopene, a powerful antioxidant, cutin, which can be used as a starting material for biopolymers, and pectin, a gelling agent. This article presents an overview of technologies that valorize tomato by-products by recovering added-value compounds as well as generating fuel for energy production. These technologies include operations for extraction, separation, and exploitation of lycopene, cutin and pectin, as well as the processes for conversion of the solid residues to fuels. Data collected from the review has been used to develop a biorefinery scheme with the related mass flow balance, for a scenario involving the tomato supply chain of Regione Campania in Italy, using tomato by-products as feedstock.
\end{abstract}

\section{INTRODUCTION}

Tomatoes (Lycopersicon esculentum Mill.) are one of the major vegetables in terms of world production, being second to potatoes only. In 2017, the global production of tomatoes amounted to 182 million tons, with China accounting for $32 \%$ of the total, followed by the European Union, India, United States and Turkey as the major producers; Italy is one of the largest producers among European nations, and the industries of Regione Campania are leaders in the sector (FAO, 2019).

While most harvested tomatoes are sold fresh, about a third is processed for traditional products like canned tomatoes, juice, paste or puree, sauces, and ketchup. The processing of tomatoes generates substantial amounts of residues, known as tomato pomace or by-products, representing $2-10 \%$ of the whole fresh tomato (Gustavsson et al., 2011; Ventura et al., 2009). Tomato pomace is a mixture of tomato cuticle (or peel), seeds and small amounts of pulp that remain after processing (Ventura et al., 2009). It is often used in animal feed (Mizael et al., 2020) as a source of dietary fiber, as well as B vitamins, lycopene and to a lesser extent vitamin A, for example, in California (which accounts for $95 \%$ of US production) most of the pomace is added to cattle feed for dairy farms. The alternative to use in animal feed is landfilling; this, for instance, represents the prevailing end-of-life route in the US Midwest. The use of tomato pomace as soil amendment after composting denotes an additional, but less common alternative (Kakabouki et al., 2021). In Italy, tomato pomace is either given for free to farmers or is sent to landfill, which represents an added cost of 200 euros per ton for the producing companies. Overall, the use of tomato pomace is limited by the risk of ruminal acidosis caused by pomace acidity (Mizael et al., 2020) or the high moisture content (60-80\% wt.) leading to fast spoiling and pollution hazard.

Tomato pomace is rich in nutrients and could be used as a potential source of fiber (60-70\% on dry basis), protein (10-20\% on dry basis), antioxidants or fat (5-10\% on dry basis) (Del Valle et al., 2006, Brachi et al., 2016a). Table 1 reports the average composition of tomato pomace including the organic macro-components.

A recent study (Benítez et al., 2018) demonstrated that cutin is the main component of the peel fraction of tomato pomace; it is a non-toxic, biodegradable, water- 
proof, UV-blocking, amorphous, insoluble and infusible bio polyester made of esterified C16 and C18 hydroxy acids (Benítez et al., 2018). Del Valle et al. (2006) reported that tomato pomace is also a source of natural pectin ( $8 \% \mathrm{wt}$. on dry basis), a thickening agent used in the food industry. Knoblich et al. (2005) investigated the tomato peel composition and proved its potential use as a source of carotenoids, natural pigments, due to its health-beneficial properties. Their results, reported in Table 2, showed that lycopene is the most abundant carotenoid in tomato processing by-products.

Tomato seeds are a specific by-product of de-seeded canned tomatoes production. They are separated from the residual tomato pomace as well as from peels by floatation. The vegetable oil contained in seeds (i.e., 20-25\% wt. on dry basis) can be recovered, for example by crushing in expellers. Tomato oil is brown in color with a strong smell and is considered suitable for dressing salads (Giuffrè and Capocasale, 2016). It contains saturated fatty acids up to $14-18 \%$ wt., and unsaturated fatty acids up to $76-80 \%$ wt. (Giuffrè and Capocasale, 2016). Its average composition is reported in Table 3.

The considerable number of high-value compounds in tomato pomace, advocates for the development of a strategy for their exploitation. Given that tomato processing by-products are classified as lignocellulosic biomass, they could be exploited through thermochemical, biological, and chemical conversion to obtain biogenic fuels, and then electricity and heat. For example, it has been reported that peels and seeds are suitable for combustion processes indeed their volatile matter and HHV (higher heating value) are significantly high after drying, which make them an interesting source for thermal energy production (Khiari et al., 2019) . Moreover, the high content of fatty acids makes tomato seed oil a good candidate to produce biodiesel (Giuffrè et al., 2016).

This article presents a brief review on the state of the art of the available techniques for the valorization of tomato by-products, in terms of extraction of high value compounds and production of energy and fuel. The review will be used as starting point for the development of a biorefinery model based on tomato pomace as feedstock and the evaluation of the related mass flow balances.

\section{EXTRACTION AND APPLICATION OF HIGH VALUE COMPOUNDS}

\subsection{Lycopene properties and extraction}

Lycopene (from the neo-Latin Lycopersicum, the tomato species) is a bright red carotenoid found in tomatoes and other red fruits, vegetables (red carrots, watermelons, gac, and papayas) and phytosynthetic algae. Due to the strong color and its solubility in organic matters, lycopene is useful as food coloring (registered as E160d) and is approved for use in the USA by the US Food and Drug Administration since 2005.

Lycopene has also been studied for its potential health effects. Promising data from epidemiological as well as cell culture and animal, studies suggest that the consumption of lycopene-containing foods may improve human health. To this end, several advanced drug delivery systems have been developed, to enhance the in vivo delivery of lycopene (Caseiro et al., 2020; Kaur et al., 2017).

In recent years, tomato peels have been proposed as a low-cost source of lycopene, compared to fresh tomatoes or Blakeslea trispora, a fungus of the division of Zygomycota, industrially used due to its ability to produce carotenoids (Górecka et al., 2020; Martínez-Cámara et al., 2018). As for the extraction of carotenoids from other plant materials, solvent extraction and supercritical $\mathrm{CO}_{2}$ extraction are the most studied and optimized techniques for lycopene extraction from tomato residues (Fritsch et al., 2017). There are numerous variables that can influence the yield of lycopene extraction, but the solvent type is widely considered to be the most important (Kaur et al., 2008). Organic solvents and their mixtures are the most investigated due to their affinity with lycopene (Briones-Labarca et al., 2019; Pandya, 2017; Zuorro, 2020).

The EU allows a small number of solvents when lycopene is to be used within the food industry (including propanol, hexane, acetone, ethanol, methanol and ethyl acetate) and a maximum solvent residue of $50 \mathrm{mg}$ per $\mathrm{kg}$ of lycopene (Commission Directive 2011/3/EU, 2011). The most promising environment-friendly alternative to traditional solvents is limonene, the major component in the essential oil of citrus fruit peels (Shakir Salih, 2015) and typically used in food industry as additive (Kim et al., 2013;

TABLE 1: Typical composition of tomato pomace on dry basis.

\begin{tabular}{|c|c|c|c|c|}
\hline Pomace fraction & Content $(\% \mathrm{w} / \mathrm{w})$ & Components & Water Content (\%) & References \\
\hline Pulp & $0-15$ & Cellulose, hemicellulose, lignin & $\approx 95$ & \multirow{3}{*}{$\begin{array}{l}\text { (Al-Wandawi et al., 1985; } \\
\text { Benítez et al., 2018; Liadakis } \\
\text { et al., 1995; Silva et al., 2019) }\end{array}$} \\
\hline Peels & $30-60$ & Cutin, pectin, hemicellulose, cellulose, extractives & $\approx 80$ & \\
\hline Seeds & $35-55$ & Hemicellulose, cellulose, lignin, lipids & $\approx 60$ & \\
\hline
\end{tabular}

TABLE 2: Carotenoid content of tomato peels on dry basis according to Knoblich et al. (2005)

\begin{tabular}{lllllll} 
Carotenoid & Lycopene & Lutein & Zeaxanthin & \multicolumn{1}{c}{$\boldsymbol{\beta}$-Carotene } & \multicolumn{1}{c}{ cis- $\boldsymbol{\beta}$-Carotene } \\
\hline Content $(\mu \mathrm{g} / \mathrm{g})$ & 734 & 14.5 & 3.7 & 29.3 & 11.7
\end{tabular}

TABLE 3: Tomato seeds oil composition on dry basis according to Giuffrè and Capocasale (2016).

\begin{tabular}{lllllll} 
Fatty acids & Stearic acid & Oleic acid & Linoleic acid & Linolenic acid & Others \\
\hline Content $(\%$ wt.) & 20 & 25 & 50 & $2-3$ & $2-3$
\end{tabular}


Ravichandran et al., 2018). Limonene, obtained from orange peels, has been also tested for lycopene extraction with results comparable to conventional organic solvents (Chemat-Djenni et al., 2010).

Solvent extraction has usually low yields due to the complex structure of the cell walls where the lycopene is trapped; moreover, degradation of the carotenoids can occur due to high temperature and long extraction time, reducing the lycopene extract quality. To overcome this problem, several techniques have been proposed in the literature, including: sonication-assisted extraction (Yilmaz et al., 2017, Rahimi and Mikani, 2019), microwave-assisted extraction (Ho et al., 2015), enzyme-assisted extraction (Ranveer, 2013; Catalkaya and Kahveci, 2019) and Naviglio extraction (Naviglio et al., 2008).

The commercial alternative to solvent extraction is supercritical fluid extraction (SFE) with $\mathrm{CO}_{2}$ being the most common working fluid. Studies on the extraction of lycopene by the means of SFE show that increasing the density of $\mathrm{CO}_{2}$ with a co-solvent (hexane or ethanol), leads to higher solubilization of the carotenoids in the fluid and, thus to an improved extraction (Baysal et al., 2000; Cadoni et al., 1999). However, recent works demonstrated that the supercritical extraction of lycopene without the use of co-solvent can reach high yields when operational parameters are optimized (Pellicanò et al., 2020). The main advantages of SFE are the high target specificity, the short extraction times, the use of a non-toxic solvent and a reduced environmental impact (Wang and Weller, 2006). On the other hand, disadvantages could be represented by SFE higher operating costs, since high pressures must be applied to maintain the fluid in supercritical state, compared to the less energy demanding operational conditions of solvent extraction. The results together with the experimental conditions of the most recent works on the extraction of lycopene from tomato peels are reported in Table 4.

The extraction processes, mentioned above, produce a fat-soluble oleoresin that contains a high concentration of lycopene and all the hydrophobic compounds that were included in the pomace; oleoresin accounts for around 5\% of tomato peels on dry weight (Brachi et al., 2016a). It is already available on the market and can be sold as produced or incorporated in products as tablets, capsules, soft gels, powders, and drinks (Nagarajan et al., 2017).

\subsection{Cutin extraction and application}

Cutin is the polymeric building block of the plant cuticle. It represents $40-80 \%$ wt. of the dry peels and consists of esterified fatty acids (Domínguez et al., 2015; Heredia, 2003). Cutin is mainly composed of mixture of C16 and C18fatty acids (Domínguez et al., 2011). These long-chain fatty acids (called cutin acids) represent innovative building-block chemicals for the synthesis of novel bio-resins and lacquers suitable as internal protective coating for metal food packaging. However, these natural compounds are not currently available commercially (Cifarelli et al., 2019). Tomato pomace and tomato peels have been proposed as a renewable source of this biopolymer, due to their high content in cutin and their availability. Cifarelli et al. (2019) reported three efficient, easy and environmentally safe procedures that could be commercialized for the extraction of cutin acids from tomato peels without the use of organic solvents, these include: i) alkaline hydrolysis of the tomato peel, ii) acid-free selective precipitation of cutin and iii) hydrogen peroxide-assisted hydrolysis. Notably, those authors noticed that the products were different depending on the method used in terms of appearance, solubility, degree of observed crosslinking and molecular weight. They

TABLE 4: Main experimental results for lycopene extraction from tomato pomace.

\begin{tabular}{|c|c|c|c|c|}
\hline Technology & Experimental conditions & Extraction solvents & $\begin{array}{l}\text { Yield of extraction } \\
\text { [on } 100 \mathrm{~g} \text { of peels] }\end{array}$ & Reference \\
\hline \multirow{4}{*}{ Solvent extraction } & $40^{\circ} \mathrm{C}$ for $5 \mathrm{~h}$ and $1: 30$ feed to solvent ratio & $\begin{array}{l}50 \% \text { acetone } \\
50 \% \text { ethyl acetate }\end{array}$ & $7.91 \mathrm{mg}$ & (Pandya, 2017) \\
\hline & $\begin{array}{l}40^{\circ} \mathrm{C} \text { for } 30 \mathrm{~min} \text { and } 1: 30 \text { feed to solvent } \\
\text { ratio }\end{array}$ & $\begin{array}{l}30.6 \% \text { hexane, } 32.8 \% \text { ethanol } \\
36.6 \% \text { acetone }\end{array}$ & $0.34 \mathrm{mg}$ & (Zuorro,2020) \\
\hline & RT and $1: 1$ feed to solvent ratio & d-Limonene & $2.44 \mathrm{mg}$ & (Chemat-Djenni et al.,2010) \\
\hline & $\begin{array}{l}\text { High pressure pre-treatment and RT for } 24 \\
\text { hour and 1:2 feed to solvent ratio }\end{array}$ & $\begin{array}{l}60 \% \text { hexane } \\
40 \% \text { ethanol }\end{array}$ & $2.08 \mathrm{mg}$ & (Briones-Labarca et al., 2019) \\
\hline \multirow{2}{*}{$\begin{array}{l}\text { Ultrasound assisted } \\
\text { extraction }\end{array}$} & $\begin{array}{l}90 \mathrm{~W} \text { for } 30 \mathrm{~min} \text { and } 1: 35 \text { feed to solvent } \\
\text { ratio }\end{array}$ & $\begin{array}{l}50 \% \text { hexane, } \\
25 \% \text { ethanol } \\
25 \% \text { acetone }\end{array}$ & $9.4 \mathrm{mg}$ & (Yilmaz et al., 2017) \\
\hline & $\begin{array}{l}70 \mathrm{~W} \text { for } 10 \mathrm{~min} \text { and } 1: 20 \text { feed to solvent } \\
\text { ratio }\end{array}$ & Sunflower oil & $9.1 \mathrm{mg}$ & (Rahimi and Mikani, 2019) \\
\hline $\begin{array}{l}\text { Microwave assisted } \\
\text { extraction }\end{array}$ & $\begin{array}{l}400 \mathrm{~W} \text { for } 1 \mathrm{~min} \text { and } 1: 20 \text { feed to solvent } \\
\text { ratio }\end{array}$ & Ethyl acetate & $13.6 \mathrm{mg}$ & (Ho et al., 2015) \\
\hline \multirow{2}{*}{$\begin{array}{l}\text { Enzyme aided } \\
\text { extraction }\end{array}$} & $\begin{array}{l}\text { Enzymatic treatment with } 2 \% \text { pectinase at } \\
4 \mathrm{~h} \text { of incubation period and subsequent } \\
\text { solvent extraction }\end{array}$ & $\begin{array}{l}50 \% \text { hexane, } \\
25 \% \text { ethanol } \\
25 \% \text { acetone }\end{array}$ & $20 \mathrm{mg}$ & (Ranveer, 2013) \\
\hline & $\begin{array}{l}\text { Enzymatic treatment with a combination } \\
\text { of cellulolytic and pectinolytic enzymes at } \\
5 \mathrm{~h} \text { of incubation period and subsequent } \\
\text { solvent extraction }\end{array}$ & Ethyl acetate & N.A. & $\begin{array}{l}\text { (Catalkaya and Kahveci, } \\
\text { 2019) }\end{array}$ \\
\hline $\begin{array}{l}\text { Supercritical fluid } \\
\text { extraction }\end{array}$ & $\begin{array}{l}80 \mathrm{~min} \text { with a pressure of } 550 \text { bar at } 60^{\circ} \mathrm{C} \\
\text { and } 2 \mathrm{ml} / \mathrm{min} \text { of solvent flow }\end{array}$ & $\mathrm{CO}_{2}$ & $37 \mathrm{mg}$ & (Pellicanò et al., 2020) \\
\hline
\end{tabular}


also noted that cutin obtained through alkaline hydrolysis resulted the best raw material for bio-resin preparation (Cifarelli et al., 2019). Manrich et al. (2017) proposed a hydrophobic edible film consisting of tomato cutin and pectin, obtained using extraction of cutin using the procedure proposed by Cigognini et al. (2015). The procedure consisted in immersing dried peels in a solution of $\mathrm{NaOH}$ and then autoclaving at $121^{\circ} \mathrm{C}$. The liquid phase was collected by filtration and then acidified to precipitate cutin, which was recovered by centrifugation, washed, and freeze-dried with a yield of $25 \%$ of dried tomato peels. Pure cutin did not lead to free-standing film and, therefore, pectin was added as a ligand to produce water-resistant tomato cutin-based films (Manrich et al., 2017). Benitez et al. (2018) proposed the production of a cutin-based polyester by melt-polycondensation without catalyst, after cutin extraction and depolymerization. Even if cutin-based resins still must be optimized, they are promising alternatives to commercial polymers used as coating for food packaging and represent a viable way to re-use industrial tomato by-products.

\subsection{Pectin extraction and application}

Pectin is a well-known, naturally occurring biopolymer that is finding increasing applications in the pharmaceutical and biotechnology industry. It has been successfully used for many years in the food and beverage industry as a thickening medium, a gelling agent, and a colloidal stabilizer (Commission Regulation (EU) No 231/2012, 2012). Moreover, pectin has several unique properties that have enabled it to be used as a matrix for the entrapment and delivery of a variety of drugs, proteins, and cells (Sriamornsak, 2003).

Although pectin is found in most plant tissues, the number of sources that may be used for the commercial manufacture of pectins are very limited. At present, commercial pectin is almost exclusively derived from citrus peels or apple pomace as by-products from juice manufacturing. The process involves extracting pectin via treatment of the pomace with hot dilute mineral acid; pectin is then recovered by precipitation with alcohol (May, 1990; Yapo et al., 2007). The main drawback of this process is represented by mineral acids, which are toxic and generate environmentally problematic effluents (Yapo, 2009). A potential alternative to mineral acids is represented by citric acid, which, has been tested for pectin extraction with comparable results (Pereira et al., 2016, Cho et al., 2019). Adiletta et al. (2019) extracted and studied pectin contained in sugar beet processing residues. They proposed for the first time the valorization of sugar beet pulp to value-added chemicals and fuels by coupling the eco-friendly isolation of pectins via citric acid extraction with the upgrading of the residual pectin-free solid as a biofuel through torrefaction.

Del Valle et al. (2006) reported that tomato peels contain pectin at $8 \%$ wt. on dry basis. Grassino et al. (2016) developed a method to produce pectin from tomato peels; in their experiments, pectin was extracted from dried tomato peels using ammonium oxalate and oxalic acid as extracting solvents, in two steps. According to their results, it can be concluded that tomato peels are a suitable source for pectin that can be used to produce corrosion inhibitors and a valuable additive in food industry. Alancay et al. (2017) optimized the pectin extraction from tomato processing waste by using a mineral acid, i.e. $\mathrm{HCl}$, thus obtaining a maximum yield of $280 \mathrm{~g} / \mathrm{kg}$ of tomato pomace. The main results from pectin extraction experiments starting from different biomasses are reported in Table 5.

\section{TOMATO RESIDUES TO ENERGY}

\subsection{Characterization, torrefaction and pelletization}

Mangut et al. (2006) provided ultimate analysis, proximate analysis, and higher heating value (HHV) of tomato pomace, after drying, with a residual moisture content around $10 \%$ wt. Their results show that the amount of sulfur is lower compared with that found in convectional fossil fuels. This outcome is interesting from environmental and technical standpoints because sulfur is well-known to generate important atmospheric pollutants and to negatively affect process plant components upon combustion. Mangut and coworkers also stated that with an HHV value of around $22 \mathrm{MJ} / \mathrm{kg}$, tomato by-products (peels, seeds and pulp) represent an interesting energy source with a high potential for heat and electricity production (Mangut et al., 2006).

Rossini et al. (2013) focused on the characterization of the tomato manufacturing residues finalized to the energy recovery. In their study they reported the physical-chemical properties of tomato by-products, and their component parts, and highlighted that nitrogen and chlorine content are considerable, especially in the seeds, this is undesirable in combustion system due to corrosion of plant components as well as serious environmental problems. To this end, they suggested to use tomato peels for combustion and seeds for the production of vegetable oil.

Brachi et al. (2016b) carried out a comprehensive

TABLE 5: Main experimental results for pectin extraction from different sources.

\begin{tabular}{|c|c|c|c|}
\hline Source of pectin & Extraction acid & Yield of extraction & Reference \\
\hline Sugar beet pulp (dried) & Sulfuric acid & $16 \%$ & (Yapo et al., 2007) \\
\hline Yellow passion fruit by-product (dried) & Lemon juice concentrate & $10 \%$ & (Yapo, 2009) \\
\hline Pomegranate peels (dried) & Citric acid & $8 \%$ & (Pereira et al.; 2016) \\
\hline Sugar beet pulp (dried) & Citric acid & $25 \%$ & (Adiletta et al., 2019) \\
\hline Apple peels (dried) & Tartaric acid & $7 \%$ & (Cho et al., 2019) \\
\hline Tomato peels(dried) & Ammonium oxalate and oxalic acid & $32 \%$ & (Grassino et al. 2016) \\
\hline Tomato peels (dried) & Hydrochloric acid & $28 \%$ & (Alancay et al., 2017) \\
\hline
\end{tabular}


study on torrefaction of dried tomato peels in a fluidized bed of inert particles, which included identification of key performance parameters and development of an experimental procedure to determine their values. Their results indicate that tomato peels are a good candidate for the torrefaction treatment. The authors also observed that higher temperatures and longer holding times (with a more marked effect of the torrefaction temperature) led to an increase in the calorific value of the torrefied tomato peels, with respect to untreated peels. For istance, when pomace is thermally treated for $30 \mathrm{~min}$ at $285^{\circ} \mathrm{C}$ the calorific value is increased by a factor of 1.2 for the torrefied biomass, with a $40 \%$ reduction in the $0 / C$ elemental ratio and an improved hydrophobicity. These positive effects of the torrefaction treatment occurred while maintaining the mass yield (approximately between $~ 75 \%$ and $~ 94 \%$ ) and energy yield at satisfactory levels. The authors also demonstrated that the fixed bed torrefaction does not ensure a consistent quality of the torrefied solid product and, consequently, a reliable determination of the key process performance parameters.

Ruiz Celma et al. (2012) investigated the feasibility of pelletizing tomato by-products for use as solid fuels. They produced fuel pellets by forcing the feed product through $6 \mathrm{~mm}$ diameter nozzles in a matrix pattern, after previous milling and air-drying process, carried out at $45^{\circ} \mathrm{C}$ drying air temperature and $1.3 \mathrm{~m} / \mathrm{s}$ drying air velocity. Their pellets had a HHV of $20 \mathrm{MJ} / \mathrm{kg}$, which is comparable to that estimated by Mangut et al. (2006) and to that of commercial wood pellets (Telmo and Lousada, 2011).

\subsection{Chemical conversion of tomato seed oil}

The use of vegetable oil for the production of biodiesel, a renewable source of energy, has multiple advantages: first, a reduction in the dependency on fossil fuels for energy production as well as a reduction of vegetal wastes; second, an increase of the economic value of crops and of vegetable oils; and third, a reduction of carbon emissions.

Giuffrè et al. (2016) firstly suggested that tomato seeds could be used for biodiesel production. The possibility of extracting oil from tomato seeds was already considered in the early 20th century. Seeds are obtained from pomace by sedimentation and pressed or extracted with solvent to produce oil, which can be refined using alkalis and then clarified with fuller's earth. The resulting oil is pale yellow and considered suitable for dressing salads. Giuffrè et al. (2016) reported that the physicochemical properties of tomato seed oil are comparable with those of rapeseed oil, that is currently used for biodiesel production in Europe. Giuffrè et al. (2017) reported a method to synthetize biodiesel from tomato seed oil. The transformation of a vegetable oil into biodiesel occurs via transesterification in a chemical reactor, in which the oil is mixed with an alcohol in the presence of a catalyst and heated. The most common alcohol used for transesterification is methanol, with potassium hydroxide being the typical catalyst. Glycerin is produced as by-products. This study showed that the resulting biodiesel can meet European regulations. In particular, the biodiesel with the best yield and composition was obtained at trans-esterification conditions with a tem- perature of $55^{\circ} \mathrm{C}$, a reaction time of $1 \mathrm{~h}$, an oil/methanol ratio $1 / 6$ and a catalyst concentration of $1 \% \mathrm{wt}$. in oil.

\section{BIOREFINERY MODEL AND MASS BAL- ANCES}

The previous sections demonstrate the significant value of tomato by-products and the availability of techniques for their valorization. In light of this, a new biorefinery model was developed for the sustainable co-production of fuel and chemicals from tomato pomace, with minimal generation of wastes. The model follows the biorefinery cascade approach (Keegan et al., 2013) and is sketched as a block diagram in Figure 1. Notably, Figure 1 only includes the main unit operations that are associated with each product.

The model assumes that tomato pomace is only composed of peels and seeds. These components are separated via floatation-cum-sedimentation and sent to different exploitation pathways. On the one hand, seeds are cold pressed with the resulting oil collected and purified. The oil is then sent to a transesterification section to produce biodiesel that meets European regulations via catalytic reaction in methanol media.

On the other hand, peels undergo several process steps in series for their complete exploitation. First, lycopene oleoresin is extracted using a mixture of organic solvents; the oleoresin is collected, purified, and used for preparing tablets that are sold as dietary supplement. Second, pectin is separated by oxalate acid extraction, collected by ethanol precipitation and washed to meet the appropriate purity for use in the food industry. Third, cutin is extracted from the solid residue, via alkaline hydrolysis; a cutin-based polyester is then produced via melt-polycondensation. The final solid residue, composed by seed residues and exhausted peels is dried, sent to a pelletizer and then torrefied to produce pellets with an HHV of around $20 \mathrm{MJ} / \mathrm{kg}$.

A general mass balance of the biorefinery model was carried out using data from literature, as reported in previous sections, including feedstock characteristics and processes yields. The mass balance shows that from 100 ton of tomato pomace on wet basis, it is possible to extract 0.6 ton of lycopene-based oleoresin, and 3 ton of cutin and 1 ton of pectin from tomato peels, whilst producing 3.9 ton of biodiesel and 0.4 ton of glycerin from tomato seed oil and methanol. In addition, it is possible to send 91.4 ton of biomass to thermal treatment (drying, torrefaction and pelletizing), producing 18.2 ton of pellets and generating 73.2 ton of emission composed mainly by removed water and gas produced during torrefaction. The results obtained from the mass balance are shown in the Sankey diagram in Figure 2.

Finally, Table 6 shows an application of the biorefinery model to the Campania region in Southern Italy, which processes nearly half of all Italian tomatoes; this corresponds to about 2.2 Mtons of fresh fruits transformed every year (Tomato News, 2019) and leads to a yearly availability of tomato by-products of around $110 \mathrm{kton}$. The table illustrates the potential production capacity of a biorefinery plant based in the Campania region. Such a plant could produce 


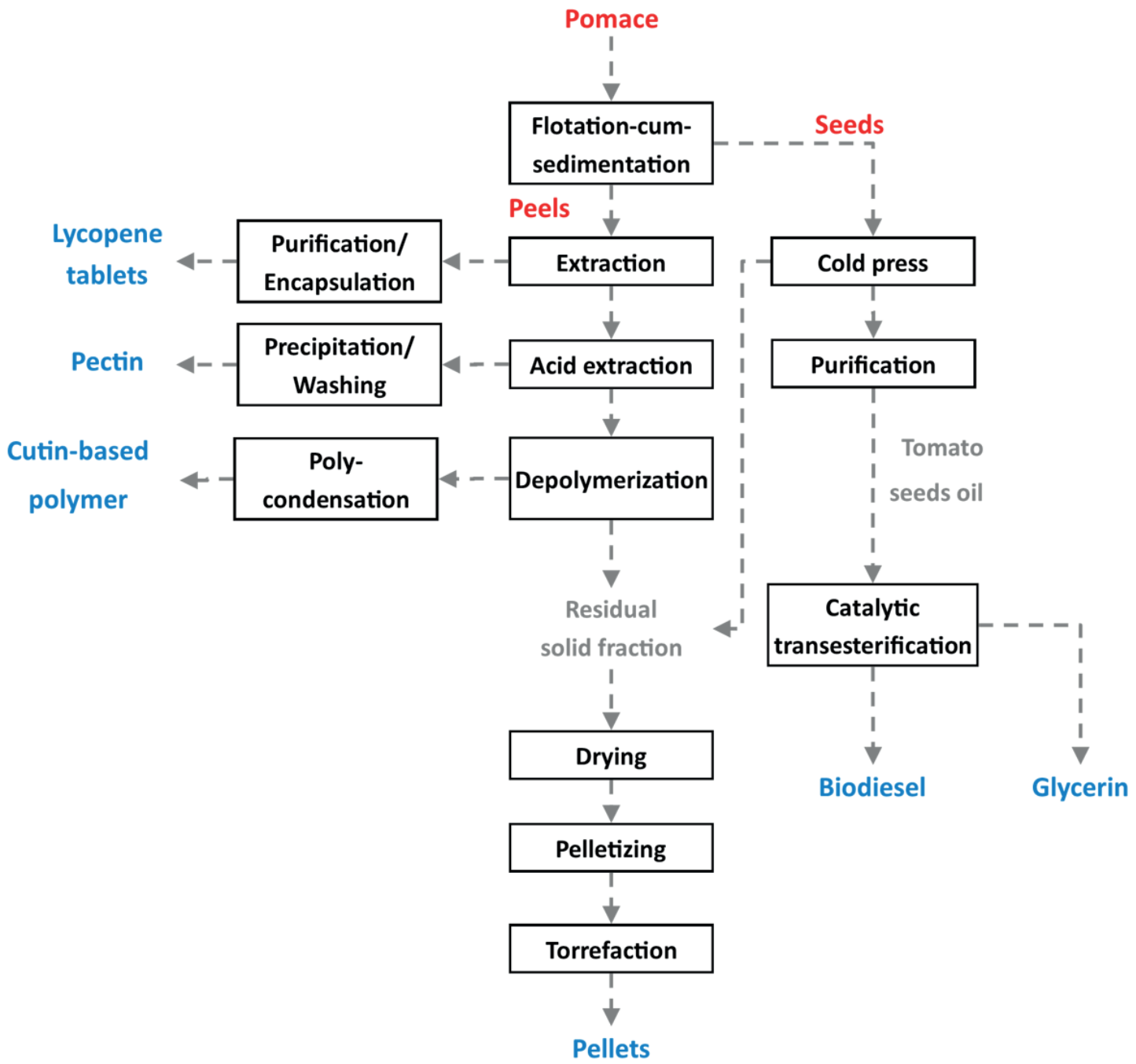

FIGURE 1: Biorefiney model for a full exploitation of tomato processing by-products (feedstocks are reported in red font, process units in black, intermediate materials in grey and biorefinery products in blue).

Methanol: 0.3

Glycerin: $0.4-$

To esterification: $4.3 \quad$ Biodiesel: 3.9 Oil: 4.0

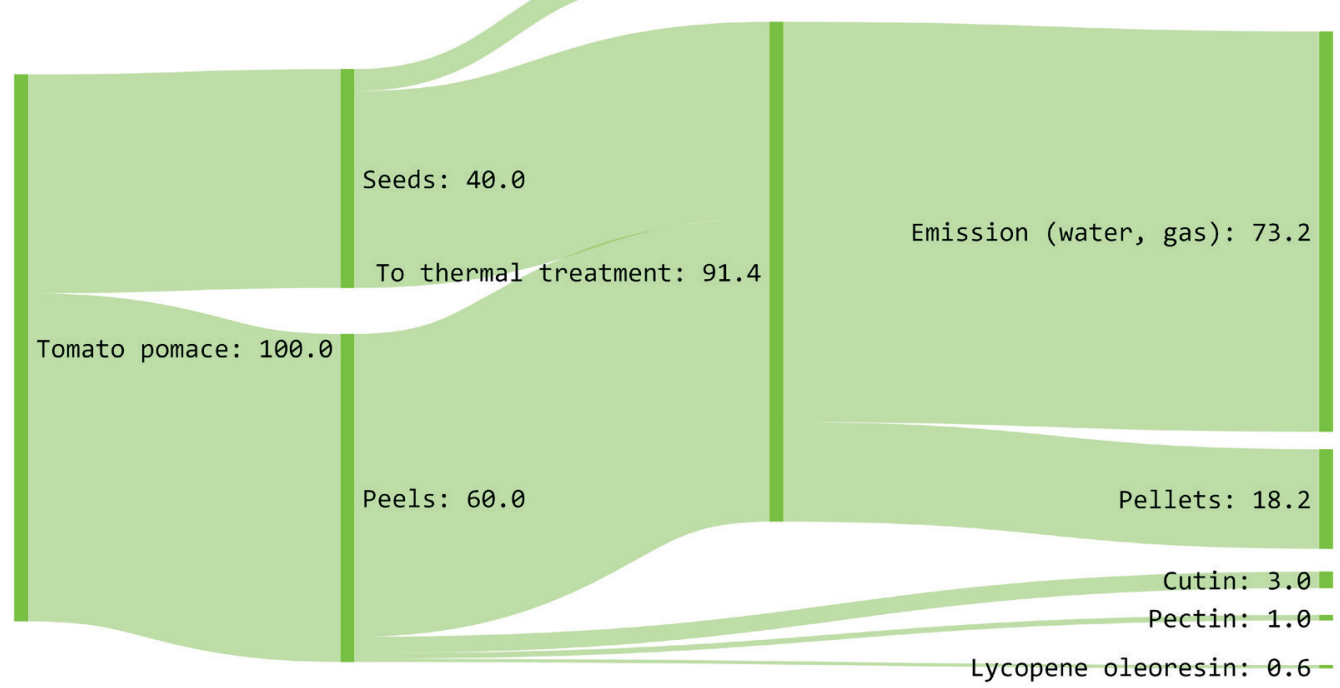

FIGURE 2: Mass balance for tomato by-products in tonnes. 
up to 1.02 kton of pectin, which covers about $3 \%$ of the European demand (Pectin Market | Apple Pectin, Fruit Pectin, Citrus Pectin, 2019) and 0.41 kton of glycerin, that is $3 \%$ of the amount of glycerin, natural and synthetic, produced in Campania in 2019 (ISTAT, 2020). With respect to the fuel and energy sector, a Campania-based biorefinery plant could contribute with 20.35 kton of pellets, i.e. $16 \%$ of all wood pellets consumption in Campania in the last 5 years (ISTAT), and with $4800 \mathrm{~m}^{3}$ of biodiesel, i.e. 3 times the Italian demand of recent years (Statista - The Statistics Portal, 2020). Moreover, such a plant could supply all Italian population with lycopene tablets during cold months, ensuring the daily requirement of $10 \mathrm{mg}$ of lycopene when fresh tomatoes are not available (Story et al., 2010).

\section{CONCLUSIONS}

This article aimed at contributing to the development and implementation of technologies for the exploitation of industrial tomato by-products that are technically feasible, economically convenient, and environmentally friendly. The article presented a thorough review of the technologies that have been proposed in the literature to valorize industrial tomato by-products, which are under-exploited and sometimes even landfilled. The review revealed that tomato pomace has high concentration of exploitable compounds: lycopene, for dietary supplement production, cutin for food packaging application, pectin as gelling agent in food industry, and tomato seed oil for biodiesel and glycerin production. Techniques to extract and purify these compounds have been demonstrated and optimized at various scales as such, they can be feasibly deployed in new process plants using tomato pomace as a feedstock. Moreover, due to their thermochemical properties, the solid residues after extraction steps, can be used for the production of pellets, after torrefaction.

Using information gathered from the literature review, it has been possible to develop a biorefinery scheme based on the valorization of tomato by-products for the sustainable co-production of fuel and chemicals, with minimal generation of waste. Although, the biorefinery scheme has only been analyzed in term of mass balances, it represents a valid background for the modeling and optimization of a multi-product biorefinery for the production of lyco- pene-based tablet, cutin-based polymer, pectin, glycerin and fuels, thus creating adding value and recovering from wasting the large amount of tomato pomace that is produced every year in the Campania region. Therefore, tomato by-products can be turned from a puzzling issue into a useful resource for the Campania in the frame of a circular economy approach.

\section{AKNOWLED GEMENTS}

This work has been carried out in the frame of the "Training on-the-job" initiative (Dottorati di ricerca con caratterizzazione industriale) funded by Regione Campania (DGR No. 156 21/03/2017 - POR Campania FSE 2014/2020 - obiettivo specifico 14 - azione 10.4.5)

\section{REFERENCES}

Adiletta, G., Brachi, P., Riianova, E., Crescitelli, A., Miccio, M., Kostryukova, N., 2020. A Simplified Biorefinery Concept for the Valorization of Sugar Beet Pulp: Ecofriendly Isolation of Pectin as a Step Preceding Torrefaction, Waste Biomass Valori., 11, 2721-2733. https://doi.org/10.1007/s12649-019-00582-4

Alancay, M. M., Lobo, M. O., Quinzio, C. M., Iturriaga, L. B., 2017. Extraction and physicochemical characterization of pectin from tomato processing waste. J. Food. Meas. Charact., 11, 2119-2130. https://doi.org/10.1007/s11694-017-9596-0

Al-Wandawi, H., Abdul-Rahman, M., Al-Shaikhly, K., 1985. Tomato processing wastes as essential raw materials source. J. Agr. Food. Chem., 33, 804-807. https://doi.org/10.1021/jf00065a009

Baysal, T., Ersus, S., Starmans, D. A. J., 2000. Supercritical $\mathrm{CO}_{2}$ extraction of $\beta$-carotene and lycopene from tomato paste waste. J. Agr. Food. Chem, 48, 5507-5511. https://doi.org/10.1021/ jf000311t

Benítez, J. J., Castillo, P. M., Del Río, J. C., León-Camacho, M., Domínguez, E., Heredia, A., Guzmán-Puyol, S., Athanassiou, A., Heredia-Guerrero, J. A., 2018. Valorization of tomato processing by-products: fatty acid extraction and production of bio-based materials. Materials, 11. https://doi.org/10.3390/ma11112211

Brachi, P., Miccio, F., Miccio, M., Ruoppolo, G., 2016a. Pseudo-component thermal decomposition kinetics of tomato peels via isoconversional methods. Fuel Process. Technol., 154, 243-250.

Brachi, P., Miccio, F., Miccio, M., Ruoppolo, G., 2016b. Torrefaction of Tomato Peel Residues in a Fluidized Bed of Inert Particles and a Fixed-Bed Reactor, http://dx.doi.org/DOI:10.1021/acs.energyfuels.6b00328, Energy Fuels, 30, 4858-4868.

Briones-Labarca, V., Giovagnoli-Vicuña, C., Cañas-Sarazúa, R., 2019. Optimization of extraction yield, flavonoids and lycopene from tomato pulp by high hydrostatic pressure-assisted extraction. Food Chem. 278, 751-759. https://doi.org/10.1016/j.foodchem.2018.11.106

TABLE 6: Production flow of biorefinery products with tomato pomace as feedstock (base case: 2.2 Mton/y of processed tomatoes in Campania).

\begin{tabular}{|c|c|c|c|}
\hline Product & Amount (unit/year) & Application & Commercial alternatives \\
\hline Tablet containing $10 \mathrm{mg}$ of lycopene & $6.610^{9}$ pills & $\begin{array}{l}\text { Dietary supplement for lycopene intake, provides an- } \\
\text { tioxidant properties that help cells fight damaging free } \\
\text { radicals in the body }\end{array}$ & $\begin{array}{l}\text { Pills containing lycopene extracted } \\
\text { from fruits }\end{array}$ \\
\hline Pectin & 1.02 kton & $\begin{array}{l}\text { In the food and beverage industry as a thickening } \\
\text { agent, a gelling agent and a colloidal stabilizer }\end{array}$ & Pectin extracted from citrus peels \\
\hline Cutin based polymer & 3.7 kton & In the food packaging field & Polyester \\
\hline Biodiesel & $4.810^{3} \mathrm{~m}^{3}$ & $\begin{array}{l}\text { In pure form or blended with petroleum diesel at any } \\
\text { concentration in most injection pump diesel engines }\end{array}$ & Biodiesel from vegetable oil \\
\hline Glycerin & 0.41 kton & $\begin{array}{l}\text { It is also widely used as a sweetener in the food indust- } \\
\text { ry and as a humectant in pharmaceutical formulations }\end{array}$ & $\begin{array}{l}\text { Generally obtained from plant and } \\
\text { animal sources }\end{array}$ \\
\hline Pellets & 20.3 kton & $\begin{array}{l}\text { Energy source with a high potential for heat and elec- } \\
\text { tricity production }\end{array}$ & Wood pellets \\
\hline
\end{tabular}


Cadoni, E., Rita De Giorgi, M., Medda, E., Poma, G., 1999. Supercritical $\mathrm{CO}_{2}$ extraction of lycopene and $\beta$-carotene from ripe tomatoes. Dyes Pigments, 44, 27-32. https://doi.org/10.1016/S01437208(99)00065-0

Caseiro, M., Ascenso, A., Costa, A., Creagh-Flynn, J., Johnson, M., Simões, S., 2020. Lycopene in human health. Lwt-Food Sci. Technol. 127, 109323. https://doi.org/10.1016/j.Iwt.2020.109323

Catalkaya, G., Kahveci, D., 2019. Optimization of enzyme assisted extraction of lycopene from industrial tomato waste. Sep. Purif. Technol. 219, 55-63. https://doi.org/10.1016/j.seppur.2019.03.006

Chemat-Djenni, Z., Ferhat, M. A., Tomao, V., Chemat, F., 2010. Carotenoid Extraction from Tomato Using a Green Solvent Resulting from Orange Processing Waste. J. Essent. Oil Bear. PI., 13, 139-147. https://doi.org/10.1080/0972060X.2010.10643803

Cho, E.-H., Jung, H.-T., Lee, B.-H., Kim, H.-S., Rhee, J.-K., Yoo, S.-H., 2019. Green process development for apple-peel pectin production by organic acid extraction. Carbohyd. Polym. 204, 97-103. https://doi. org/10.1016/j.carbpol.2018.09.086

Cigognini, I., Montanari, A., Carrerars, R. D. L. T., Montserrat, G. C. B., 2015. Extraction method of a polyester polymer or cutin from the wasted tomato peels and polyester polimer so extracted (World Intellectual Property Organization Patent N. W02015028299A1). https://patents.google.com/patent/WO2015028299A1/en

Cifarelli, A., Cigognini, I. M., Bolzoni, L., Montanari, A., 2019. Physicalchemical characteristics of cutin separated from tomato waste for the preparation of bio-lacquers. Adv. Sci. Eng., 11, 33-45. https:// doi.org/10.32732/ase.2019.11.1.33

Commission Directive 2011/3/EU, COM, OJ L 013 (2011). http://data. europa.eu/eli/dir/2011/3/oj/eng

Del Valle, M., Cámara, M., Torija, M.-E., 2006. Chemical characterization of tomato pomace. J. Sci. Food Agr., 86, 1232-1236. https://doi. org/10.1002/jsfa.2474

Domínguez, E., Heredia-Guerrero, J. A., Heredia, A., 2011. The biophysical design of plant cuticles: an overview. New Phytol., 189, 938949. https://doi.org/10.1111/j.1469-8137.2010.03553.x

Domínguez, E., Heredia-Guerrero, J. A., Heredia, A., 2015. Plant cutin genesis: unanswered questions. Trends Plant Sci., 20, 551-558. https://doi.org/10.1016/j.tplants.2015.05.009

Commission Regulation (EU) No 231/2012, Pub. L. No. 32012R0231, 083 OJ L (2012). http://data.europa.eu/eli/reg/2012/231/oj/eng

FAO. (2019). Food and Agriculture Organization of the United Nations. http://www.fao.org/home/en/

Fritsch, C., Staebler, A., Happel, A., Cubero Márquez, M. A., Aguiló-Aguayo, I., Abadias, M., Gallur, M., Cigognini, I. M., Montanari, A., López, M. J., Suárez-Estrella, F., Brunton, N., Luengo, E., Sisti, L., Ferri, M., Belotti, G., 2017. Processing, valorization and application of bio-waste derived compounds from potato, tomato, olive and cereals: a review. Sustainability-Basel, 9, 1492. https://doi. org/10.3390/su9081492

Giuffrè, A. M., Capocasale, M., Zappia, C., Poiana, M., 2017. Biodiesel from tomato seed oil: transesterification and characterisation of chemical-physical properties. Agron. Res., 15, 133-143.

Giuffrè, A., Capocasale, M., 2016. Physicochemical composition of tomato seed oil for an edible use: The effect of cultivar. International Food Res. J. 23, 583-591.

Giuffrè, A. M., Capocasale, M., Zappia, C., Sicari, V., Pellicanò, T. M., Poiana, M., Panzera, G., 2016. Tomato seed oil for biodiesel production. Eur. J. Lipid Sci. Tech., 118, 640-650. https://doi. org/10.1002/ejlt.201500002

Górecka, D., Wawrzyniak, A., Jedrusek-Golińska, A., Dziedzic, K., Hamułka, J., Kowalczewski, P.Ł., Walkowiak, J., 2020. Lycopene in tomatoes and tomato products. Open Chem. 18, 752-756. https://doi. org/10.1515/chem-2020-0050

Grassino, A. N., Halambek, J., Djaković, S., Rimac Brnčić, S., Dent, M. Grabarić, Z., 2016. Utilization of tomato peel waste from canning factory as a potential source for pectin production and application as tin corrosion inhibitor. Food Hydrocoll., 52, 265-274. https:// doi.org/10.1016/j.foodhyd.2015.06.020

Gustavsson, J., Cederberg, C., Sonesson, U., 2011. Global food losses and food waste: extent, causes and prevention; study conducted for the International Congress Save Food! at Interpack 2011, [1617 May], Düsseldorf, Germany. Food and Agriculture Organization of the United Nations.

Heredia, A., 2003. Biophysical and biochemical characteristics of cutin, a plant barrier biopolymer. Biochim. Biophys. Acta, 1620, 1-7. https://doi.org/10.1016/s0304-4165(02)00510-x
Ho, K. K. H. Y., Ferruzzi, M. G., Liceaga, A. M., San Martín-González, M. F., 2015. Microwave-assisted extraction of lycopene in tomato peels: Effect of extraction conditions on all-trans and cis-isomer yields. LWT-Food Sci. Technol., 62, 160-168. https://doi.org/10.1016/j. wht.2014.12.061

ISTAT. (2020). Istituto Nazionale di Statistica. https://www.istat.it/

Kakabouki, I., Folina, A., Efthimiadou, A., Karydogianni, S., Zisi, C., Kouneli, V., Kapsalis, N.C., Katsenios, N., Travlos, I., 2021. Evaluation of Processing Tomato Pomace after Composting on Soil Properties, Yield, and Quality of Processing Tomato in Greece. Agron. 11, 88. https://doi.org/10.3390/agronomy11010088

Kaur, D., Wani, A. A., Oberoi, D. P. S., Sogi, D. S., 2008. Effect of extraction conditions on lycopene extractions from tomato processing waste skin using response surface methodology. Food Chem. 108, 711-718. https://doi.org/10.1016/j.foodchem.2007.11.002

Kaur, G., Sandal, A., Dhillon, N., 2017. Lycopene and human health-A review. Agric. Rev. 38, 282-289. https://doi.org/10.18805/ag.R-1741

Keegan, D., Kretschmer, B., Elbersen, B., Panoutsou, C., 2013. Cascading use: a systematic approach to biomass beyond the energy sector. Biofuel. Bioprod. Biorefin., 7, 193-206. https://doi. org/10.1002/bbb.1351

Khiari, B., Moussaoui, M. Jeguirim, M., 2019. Tomato-Processing By-Product Combustion: Thermal and Kinetic Analyses. Mater. 12, 553. https://doi.org/10.3390/ma12040553

Kim, Y. W., Kim, M. J., Chung, B. Y., Bang, D. Y., Lim, S. K., Choi, S. M., Lim, D. S., Cho, M. C., Yoon, K., Kim, H. S., Kim, K. B., Kim, Y. S., Kwack, S. J., Lee, B.-M., 2013. Safety evaluation and risk assessment of d-limonene. J. Toxicol. Env. Heal. B, 161, 17-38. https://doi.org/10 .1080/10937404.2013.769418

Knoblich, M., Anderson, B., Latshaw, D., 2005. Analyses of tomato peel and seed by-products and their use as a source of carotenoids. J. Sci. Food Agr., 85, 1166-1170. https://doi.org/10.1002/jsfa.2091

Liadakis, G. N., Tzia, C., Oreopoulou, V., Thomopoulos, C. D., 1995. Protein isolation from tomato seed meal, extraction optimization. J. Food Sci., 60, 477-482. https://doi.org/10.1111/j.1365-2621.1995. tb09807.x

Mangut, V., Sabio, E., Gañán, J., González, J. F., Ramiro, A González, C. M., Román, S., Al-Kassir, A., 2006. Thermogravimetric study of the pyrolysis of biomass residues from tomato processing industry. Fuel Process. Technol., 87, 109-115. https://doi.org/10.1016/j. fuproc.2005.08.006

Manrich, A., Moreira, F. K. V., Otoni, C. G., Lorevice, M. V., Martins, M. A., Mattoso, L. H. C., 2017. Hydrophobic edible films made up of tomato cutin and pectin. Carbohyd. Polym., 164, 83-91. https:// doi.org/10.1016/j.carbpol.2017.01.075

Martínez-Cámara, S., Rubio, S., Del Río, H., Rodríguez-Sáiz, M., Barredo, J.-L., 2018. Lycopene Production by Mated Fermentation of Blakeslea trispora. In: Barreiro C., Barredo JL. (eds) Microbial Carotenoids. Methods in Molecular Biology, vol 1852. Humana Press, New York, NY. https://doi.org/10.1007/978-1-4939-8742-9_15

May, C. D., 1990. Industrial pectins: sources, production and applications. Carbohyd. Polym., 12, 79-99. https://doi.org/10.1016/01448617(90)90105-2

Mizael, W., Costa, R., Rodrigo, G., Cruz, B., Carvalho, F., Ribeiro, N., Lima, A., Domínguez, R., Lorenzo, J.M., 2020. Effect of the Use of Tomato Pomace on Feeding and Performance of Lactating Goats. Animals 10, 1574. https://doi.org/10.3390/ani10091574

Nagarajan, J., Ramanan, R.N., Raghunandan, M.E., Galanakis, C.M., Krishnamurthy, N.P., 2017. Chapter 8-Carotenoids. IN: Galanakis, C.M. (eds.), Nutraceutical and Functional Food Components. Academic Press. https://doi.org/10.1016/B978-0-12-805257-0.00008-9

Naviglio, D., Caruso, T., Iannece, P., Aragòn, A., Santini, A., 2008. Characterization of high purity lycopene from tomato wastes using a new pressurized extraction approach. J. Agr. Food Chem., 56 6227-6231. https://doi.org/10.1021/jf703788c

Pandya, D., 2017. Standardization of Solvent Extraction Process for Lycopene Extraction from Tomato Pomace. J. Appl. Biotechnol. Bioen. 2, 12-16. https://doi.org/10.15406/jabb.2017.02.00019

Pectin Market | Apple Pectin, Fruit Pectin, Citrus Pectin. (2019). https:// industry-experts.com/verticals/food-and-beverage/pectin-a-global-market-overview

Pellicanò, T.M., Sicari, V., Loizzo, M.R., Leporini, M., Falco, T., Poiana, M. 2020. Optimizing the supercritical fluid extraction process of bioactive compounds from processed tomato skin by-products. Food Sci. Technol. 40, 692-697. https://doi.org/10.1590/fst.16619 
Pereira, P. H. F., Oliveira, T. Í. S., Rosa, M. F., Cavalcante, F. L., Moates, G. K., Wellner, N., Waldron, K. W., Azeredo, H. M. C., 2016. Pectin extraction from pomegranate peels with citric acid. Int. J. Biol. Macromol., 88, 373-379. https://doi.org/10.1016/j.ijbiomac.2016.03.074

Rahimi, S., Mikani, M., 2019. Lycopene green ultrasound-assisted extraction using edible oil accompany with response surface methodology (RSM) optimization performance: Application in tomato processing wastes. Microchem. J. 146, 1033-1042. https://doi. org/10.1016/j.microc.2019.02.039

Ranveer, R.C., Patil, S.N., Sahoo, A.K., 2013. Effect of different parameters on enzyme-assisted extraction of lycopene from tomato processing waste. Food Bioprod. Process. 91, 370-375. https://doi. org/10.1016/j.fbp.2013.01.006

Ravichandran, C., Badgujar, P. C., Gundev, P., Upadhyay, A., 2018. Review of toxicological assessment of d-limonene, a food and cosmetics additive. Food Chem. Toxicol., 120, 668-680. https://doi. org/10.1016/j.fct.2018.07.052

Rossini, G., Toscano, G., Duca, D., Corinaldesi, F., Foppa Pedretti, E. Riva, G., 2013. Analysis of the characteristics of the tomato manufacturing residues finalized to the energy recovery. Biomass Bioener., 51, 177-182. https://doi.org/10.1016/j.biombioe.2013.01.018

Ruiz Celma, A., Cuadros, F., López-Rodríguez, F., 2012. Characterization of pellets from industrial tomato residues. Food Bioprod. Process., 90, 700-706. https://doi.org/10.1016/j.fbp.2012.01.007

Shakir, I. K., Salih, S. J., 2015. Extraction of essential oils from citrus by-products using microwave steam distillation. Iraqi Journal of Chemical and Petroleum Engineering, 16, 11-22.

Silva, Y. P. A., Borba, B. C., Pereira, V. A., Reis, M. G., Caliari, M., Brooks, M. S.-L., Ferreira, T. A. P. C., 2019. Characterization of tomato processing by-product for use as a potential functional food ingredient: nutritional composition, antioxidant activity and bioactive compounds. Int. J. Food Sci. Nutr., 70, 150-160. https://doi.org/1 $0.1080 / 09637486.2018 .1489530$
Sriamornsak, P., 2003. Chemistry of pectin and its pharmaceutical uses: a review. Silpakorn Univ. J. Soc. Sci. Humanit. Arts, 3, 206 https://www.scienceopen.com/document?vid=4b41 efab-82224f0d-9ade-2559a820718c

Tomato News., 2019. http://www.tomatonews.com/en/background_47.html

Telmo, C., Lousada, J., 2011. Heating values of wood pellets from different species. Biomass Bioener., 35, 2634-2639. https://doi. org/10.1016/j.biombioe.2011.02.043

Ventura, M. R., Pieltain, M. C., Castanon, J. I. R., 2009. Evaluation of tomato crop by-products as feed for goats. Anim. Feed Sci. Tech., 154, 271-275. https://doi.org/10.1016/j.anifeedsci.2009.09.004

Wang, L., Weller, C. L., 2006. Recent advances in extraction of nutraceuticals from plants. Trends Food Sci. Tech., 17, 300-312. https:// doi.org/10.1016/j.tifs.2005.12.004

Yapo, B. M., 2009. Lemon juice improves the extractability and quality characteristics of pectin from yellow passion fruit by-product as compared with commercial citric acid extractant. Bioresource Technol., 100, 3147-3151. https://doi.org/10.1016/j. biortech.2009.01.039

Yapo, B. M., Robert, C., Etienne, I., Wathelet, B., Paquot, M., 2007. Effect of extraction conditions on the yield, purity and surface properties of sugar beet pulp pectin extracts. Food Chem., 100, 1356-1364. https://doi.org/10.1016/j.foodchem.2005.12.012

Yilmaz, T., Kumcuoglu, S., Tavman, S., 2017. Ultrasound Assisted Extraction of Lycopene and $\mathrm{b}$-carotene from Tomato Processing Wastes. Ital. J. Food Sci. 29. https://doi.org/10.14674/1120-1770/ ijfs.v481

Zuorro, A., 2020. Enhanced lycopene extraction from tomato peels by optimized mixed-polarity solvent mixtures. Molecules 25. https:// doi.org/10.3390/molecules25092038 